\title{
Coumarins from Creston Apple Seeds: Isolation, Chemical Modification, and Cytotoxicity Study
}

\author{
Yasser Fakri Mustafa ${ }^{1 *}$, Moath Abdulla Najem², Zena Sideek Tawffiq ${ }^{3}$ \\ ${ }^{1}$ The University of Mosul, College of Pharmacy, Department of Pharmaceutical Chemistry, Mosul, Iraq. \\ ${ }^{2}$ The University of Mosul, College of Agriculture and Forestry, Department of Basic Sciences, Mosul, Iraq. \\ ${ }^{3}$ The University of Mosul, College of Pharmacy, Department of Pharmacognosy, Mosul, Iraq.
}

\section{ARTICLE INFO \\ Article history: \\ Received on: 02/05/2018 \\ Accepted on: 24/07/2018 \\ Available online: $31 / 08 / 2018$}

\section{Key words:}

Creston apple, phytochemical, coumarin derivative, cytotoxicity.

\begin{tabular}{l}
\hline ABSTRACT \\
\hline In the present work, preliminary phytochemical screening tests were performed on extracts of Creston apple seeds. \\
Extraction was performed using two methods, which are serial Soxhlet extraction and kinetic maceration utilizing water, \\
methanol, chloroform, and n-hexane as extraction solvents. Three coumarin derivatives acquired from chloroform \\
extract in the order of increasing polarity were isolated via column chromatography and one of them was chemically \\
modified by esterification, Fries rearrangement, and methylation afforded three semisynthetic derivatives. Detection \\
of physicochemical properties and analysis of FTIR, ${ }^{1} \mathrm{H}-\mathrm{NMR}$ and ${ }^{13} \mathrm{C}-\mathrm{NMR}$ spectra of the natural and semisynthetic \\
coumarins were used to identify their structures. In vitro cytotoxic activity of the aforementioned coumarin derivatives \\
was studied on three cancer cell lines, which are MCF-7, AMN3, and HeLa using MTT assay. The results indicated \\
that compounds $\mathrm{N} 3, \mathrm{~S} 4, \mathrm{~S}_{5}$ and $\mathrm{S} 6$ have $\mathrm{IC}_{50}$ values lower than that of 5- fluorouracil against MCF-7 cell line and all \\
compounds have higher $\mathrm{IC}_{50}$ values than that of 5-fluorouracil against AMN3 and HeLa cell lines.
\end{tabular}

\section{INTRODUCTION}

Cancer is a major public health problem and is the second leading cause of death worldwide. According to the American Cancer Society, there were 1.7 million new cancer cases and 0.6 million cancer deaths throughout the United States nationally in 2018 (Siegel et al., 2018).

During the last decades, natural products and their derivatives played an influential role in drug discovery and development programs because of their enormous biological properties (Crane and Gademann, 2016) and their effectiveness in treating several human diseases, including cancer (Newman and Cragg, 2016). Although the molecular mechanisms of action for most of these compounds are yet uncertain, recent evidence arises from molecular biology, high throughput screening, proteomic and genomic approaches can enable many researchers to collect some pieces of the fact (Kok et al., 2012; Li-Weber, 2015; Tsuchiya, 2015).

\section{"Corresponding Author}

Yasser Fakri Mustafa, The University of Mosul, College of Pharmacy, Department of Pharmaceutical Chemistry.

E-mail:Dr.yassermustafa@uomosul.edu.iq
Coumarin (1,2-benzopyrone, 2H-1-benzopyran-2-one, or phenylpropanoids, Fig. 2) and its derivatives are a family of oxygen-containing fused heterocycles and they are widely distributed throughout nature (Swayam et al., 2012). Until 2013, more than 1,300 coumarins have been identified as secondary metabolites in different plants, bacteria and fungi (Venugopala et al., 2013). In the plant kingdom, coumarins are found in over 30 different families as Umbelliferae, Rutaceae and Clusiaceae (Stefanachi et al., 2018) and they are distributed in various parts of these plants especially seeds, roots and leaves (Rosselli et al., 2009).

Creston apple (Malus domestica, Pomoideae subfamily, Rosaceae family) is a name of both the tree and fruit. As a tree, it is cultivated worldwide and is originated in Central Asia where its wild ancestor, Malus sieversii, is still found today. Also, this tree has been grown for thousands of years in Asia and Europe and was brought to North America by European colonists (Quamme et al., 1999).

The seeds of Creston apple are mildly poisonous due to the presence of a small amount of cyanogenic glycoside called amygdalin; the amount of which $(0.6 \mathrm{mg} / \mathrm{g}$ of seeds) is relatively low and is unlikely to cause harmful effect to humans, but it is 
possible to cause that effect when extremely high amount of seeds has been consumed (Nelson et al., 2007).

According to our survey conducted in September 2017, the available reports regarding the phytochemicals of Creston apple studied them in whole fruit without seeds (Jelodarian et al., 2012; Anbu Jeba Sunilson et al., 2016), peel (Konarska, 2013; Vineetha et al., 2014) or leaves (Liaudanskas et al., 2014; Sowa et $a l ., 2016)$. We failed to find any data on the chemical composition of the Creston apple seeds, which provides a motive to initiate this work.

The aim of this work is to carry out phytochemical screening tests on four different extracts (water, methanol, chloroform and n-hexane) obtained from Creston apple seeds (using serial Soxhlet extraction and kinetic maceration), to isolate any coumarins found in the extracts (compounds $\mathbf{N} 1, \mathbf{N} 2$ and N3) and then chemically modifying $\mathbf{N} \mathbf{3}$ to afford new semisynthetic derivatives (compounds $\mathbf{S 4 , ~} \mathbf{S 5}$ and $\mathbf{S 6}$ ), and finally to screen the cytotoxic activity of the isolated coumarins and their semisynthetic derivatives on three cancer cell lines, which are: MCF-7, AMN3 and HeLa using MTT assay.

\section{MATERIAL AND METHODS}

The chemicals and solvents used in the extraction and synthesis were purchased from Sigma-Aldrich and Tokyo Chemical Industry (TCI), and they were utilized without further purification. The chemicals and reagents used in a cytotoxic study included the following: Trypsin/EDTA (T4049), Roswell Park Memorial Institute (RPMI) 1640 medium (R8758) and fetal bovine serum (F2442) were purchased from Sigma-Aldrich while MTT stain (42000092-1) was obtained from Bio-World. The fruit was purchased from the local market and the taxonomic identity for 30 plant specimens was confirmed by the College of Agriculture and Forestry/University of Mosul.

Solvent Extractor SER 148 Series (VELP Scientifica) was used for serial Soxhlet extraction, while for kinetic maceration, SWBR17 SHEL LAB shaking water bath was used. Bruker-Alpha ATR was used to scan IR spectra, and Varian UV/ Visible spectrophotometer was used to identify the IR spectra of the products. Among other UV absorption bands, the wavelength of maximum absorption $\left(\lambda_{\max }\right)$ was utilized in this work. Protonnuclear magnetic resonance ( $\left.{ }^{1} \mathrm{H}-\mathrm{NMR}\right)$ and carbon-nuclear magnetic resonance $\left({ }^{13} \mathrm{C}\right.$-NMR) spectra of products were scanned on Bruker Avance 300 and $400 \mathrm{MHz}$, respectively.

\section{EXTRACTION}

\section{Preparation of sample}

After authentication, Creston apples (100 kg) were washed properly with running water, then with distilled water and sliced manually into small pieces. The obtained seeds were shade dried at room temperature for 2 weeks, pulverized in a blender, and sieved affording a fine powder (138.4 g) which was placed in amber tightly-closed containers in the refrigerator for further use (Mahlo et al., 2016).

\section{Serial Soxhlet extraction}

Powdered material (20 g) was extracted successively in Soxhlet with $200 \mathrm{~mL}$ of each of the following solvents: water, methanol, chloroform, and n-hexane; once in order of decreasing polarity and secondly in the order of increasing polarity. Each time before extracting with the next solvent, the powdered material was dried. The extracts were filtered using Whitman No.1 filter paper and the resulted solutions were concentrated under reduced pressure, stored in amber tightly-closed containers apparently labeled and kept in the refrigerator until used for phytochemical screening tests (Apu et al., 2012).

\section{Extraction by kinetic maceration}

Powdered material (2.5 g) was added to a beaker containing $25 \mathrm{~mL}$ of water, methanol, chloroform or $\mathrm{n}$-hexane placed in a shaker water bath adjusted at $37^{\circ} \mathrm{C}$ for 24 hours. The extracts were filtered using Whitman No. 1 filter paper and the resulted solutions were concentrated under reduced pressure, stored in amber tightly-closed containers apparently labeled and kept in the refrigerator until used for phytochemical screening tests (Naviglio et al., 2016).

\section{QUALITATIVE PHYTOCHEMICAL SCREENING TESTS}

Extracts obtained from the previously mentioned extraction methods were subjected separately to the phytochemical screening tests reported by Harborne (Harborne, 1998).

\section{ISOLATION OF COUMARINS}

The chloroform extract was dried under reduced pressure. The solid was treated with $50 \mathrm{~mL}$ of $1 \mathrm{~N} \mathrm{NaOH}$ and stirred using a condenser apparatus at $50^{\circ} \mathrm{C}$ for 3 hours. The mixture was filtered and the resulted yellow filtrate was acidified with $1 \mathrm{~N} \mathrm{HCl}$; the crystals were collected via filtration after cooling the mixture for 24 hours in the refrigerator.

The TLC plate eluted with $\mathrm{CHCl}_{3}$ : acetone (4:1) indicated the presence of three spots; accordingly, the separation was conducted via column chromatography using silica gel as a stationary phase and mixture of ethyl acetate: ether as an eluent in gradient ratio ranging from 1:9 to $9: 1$.

Three compounds (N1, N2 and N3) ( $\mathrm{N}$ for natural) were identified respectively, each one as a single spot, in the following fractions: (7:3), (5:5) and (9:1) (Ghanbari et al., 2011).

5,6-dihydropyrone (4,3-g)coumarin (N1) white powder from a mixture of ether: $\mathrm{CHCl}_{3}(1: 3) ;$ m.p $176-178^{\circ} \mathrm{C} ; \lambda_{\text {max }}(\mathrm{EtOH})$ $323 \mathrm{~nm} ; \mathrm{R}_{\mathrm{f}}$ 0.846; IR ( $v, \mathrm{~cm}^{-1}$ ): 3056 (=C-H str.), 2980 (C-H str., alkyl), $1724(\mathrm{C}=\mathrm{O}$ str., ester $), 1670(\mathrm{C}=\mathrm{C}$ str. $), 1585(\mathrm{C}=\mathrm{C}$ str., aromatic), 1267 (C-O str., ester); ${ }^{1} \mathrm{H}-\mathrm{NMR}\left(\mathrm{CDCl}_{3}, 300 \mathrm{MHz}\right) \delta$ ppm: 8.4 (s, 1H, C5-H), 7.8 (d, 1H, $J=9.6 \mathrm{~Hz}, \mathrm{C} 4-\mathrm{H}), 7.1$ (s, $1 \mathrm{H}, \mathrm{C} 8-\mathrm{H}), 6.5$ (d, 1H, $J=9.6 \mathrm{~Hz}, \mathrm{C} 3-\mathrm{H}), 4.7$ (t, 2H, $J=6.0$ $\left.\mathrm{Hz}, \mathrm{O}-\mathrm{CH}_{2}-\mathrm{CH}_{2}\right), 3.0\left(\mathrm{t}, 2 \mathrm{H}, J=6.0 \mathrm{~Hz}, \mathrm{O}-\mathrm{CH}_{2}-\mathrm{CH}_{2}\right) ;{ }^{13} \mathrm{C}-\mathrm{NMR}$ $\left(\mathrm{CDCl}_{3}, 100 \mathrm{MHz}\right) \delta \mathrm{ppm}: 168.3(\mathrm{C} 6-\mathrm{C}=\mathrm{O}), 161.5(\mathrm{C} 2), 156.7$ (C9), 146.0 (C4), 140.3 (C7), 128.1 (C5), 127.7 (C6), 127.2 (C10), 120.1 (C8), 117.2 (C3), $72.3\left(\mathrm{O}-\mathrm{CH}_{2}-\mathrm{CH}_{2}\right), 30.8\left(\mathrm{O}-\mathrm{CH}_{2}-\mathrm{CH}_{2}\right)$.

5-Ethyl-6,7-dimethylcoumarin (N2) white powder from a mixture of EtOH: $\mathrm{CHCl}_{3}$ (1:2); m.p 121-123 ${ }^{\circ} \mathrm{C}$; $\lambda_{\text {max }}(\mathrm{EtOH}) 326$ $\mathrm{nm} ; \mathrm{R}_{\mathrm{f}}$ 0.830; IR ( $\left.\mathrm{v}, \mathrm{cm}^{-1}\right): 3035$ (=C-H str.), 2950, 2883 (C-H str., alkyl), 1700 ( $\mathrm{C}=\mathrm{O}$ str., ester $), 1666(\mathrm{C}=\mathrm{C}$ str. $), 1588(\mathrm{C}=\mathrm{C}$ str., aromatic), 1270 (C-O str., ester); ${ }^{1} \mathrm{H}-\mathrm{NMR}\left(\mathrm{CDCl}_{3}, 300 \mathrm{MHz}\right) \delta$ ppm: 7.9 (d, 1H, $J=9.6 \mathrm{~Hz}, \mathrm{C} 4-\mathbf{H}), 6.8(\mathrm{~s}, 1 \mathrm{H}, \mathrm{C} 8-\mathbf{H}), 6.4(\mathrm{~d}$, $1 \mathrm{H}, J=9.6 \mathrm{~Hz}, \mathrm{C} 3-\mathbf{H}), 2.6\left(\mathrm{~m}, 2 \mathrm{H}, J=6.3 \mathrm{~Hz}, \mathrm{C} 5-\mathrm{CH}_{2}-\mathrm{CH}_{3}\right)$, $2.4\left(\mathrm{~s}, 3 \mathrm{H}, \mathrm{C} 6-\mathrm{CH}_{3}\right), 2.2\left(\mathrm{~s}, 3 \mathrm{H}, \mathrm{C} 7-\mathrm{CH}_{3}\right), 1.2(\mathrm{t}, 3 \mathrm{H}, J=6.3 \mathrm{~Hz}$, 
$\left.\mathrm{C} 5-\mathrm{CH}_{2}-\mathrm{CH}_{3}\right) ;{ }^{13} \mathrm{C}-\mathrm{NMR}\left(\mathrm{CDCl}_{3}, 100 \mathrm{MHz}\right) \delta \mathrm{ppm}: 163.1(\mathrm{C} 2)$, 147.9 (C9), 147.3 (C4), 137.9 (C5), 137.5 (C7), 134.3 (C6), 124.9 (C10), 120.0 (C8), 116.1 (C3), $17.0\left(\mathrm{C}^{-}-\mathrm{CH}_{2}-\mathrm{CH}_{3}\right), 16.2$ $\left(\mathrm{C} 5-\mathrm{CH}_{2}-\mathrm{CH}_{3}\right), 14.5\left(\mathrm{C} 7-\mathrm{CH}_{3}\right), 9.0\left(\mathrm{C} 6-\mathrm{CH}_{3}\right)$.

7-Hydroxy-4-methoxycoumarin (N3) white powder from a mixture of EtOH: $\mathrm{CHCl}_{3}(1: 1)$; m.p $164-166^{\circ} \mathrm{C} ; \lambda_{\max }(\mathrm{EtOH}) 322$ $\mathrm{nm} ; \mathrm{R}_{\mathrm{f}}$ 0.727; IR ( $\left.\mathrm{v}, \mathrm{cm}^{-1}\right)$ : 3300 (O-H str., phenol), 3076 (=C-H str.), 2898 (C-H str., alkyl), 1708 (C=O str., ester), $1678(\mathrm{C}=\mathrm{C}$ str.), 1573 (C=C str., aromatic), 1302 (asymmetrical C-O-C str., ether), 1169 (C-O str., ester), 1064 (symmetrical C-O-C str., ether); ${ }^{1} \mathrm{H}-\mathrm{NMR}\left(\mathrm{CDCl}_{3}, 300 \mathrm{MHz}\right) \delta \mathrm{ppm}$ : 10.1 (s, 1H, O-H), 7.6 $(\mathrm{d}, 1 \mathrm{H}, J=9 \mathrm{~Hz}, \mathrm{C} 5-\mathrm{H}), 6.7$ (d, $1 \mathrm{H}, J=9 \mathrm{~Hz}, \mathrm{C} 6-\mathrm{H}), 6.6(\mathrm{~s}, 1 \mathrm{H}$, $\mathrm{C} 8-\mathrm{H}), 5.5$ (s, 1H, C3-H), 3.6 (s, 3H, O-CH $)$; ${ }^{13} \mathrm{C}-\mathrm{NMR}\left(\mathrm{CDCl}_{3}\right.$, $100 \mathrm{MHz}) \delta$ ppm: $176.6(\mathrm{C} 4), 162.7$ (C2), 157.2 (C7), $150.6(\mathrm{C} 9)$, 128.8 (C5), 121.7 (C10), 113.4 (C6), 105.5 (C8), 88.2 (C3), 50.6 $\left(\mathrm{O}-\mathrm{CH}_{3}\right)$.

\section{CHEMICAL SYNTHESIS OF COMPOUND (N3) DERIVATIVES (SCHEME 1)}

\section{Synthesis of 7-Acetoxy-4-methoxycoumarin (S4)}

A mixture of $\mathbf{N 3}(1.92 \mathrm{~g}, 10 \mathrm{mmol})$ and anhydrous $\mathrm{K}_{2} \mathrm{CO}_{3}(2.76 \mathrm{~g}, 20 \mathrm{mmol})$ in $30 \mathrm{~mL}$ ethanol was stirred for 30 minutes at room temperature and then concentrated under reduced pressure. The solid was filtered, re-dissolved in $40 \mathrm{~mL}$ acetone and filtered. The filtrate was evaporated to afford a sodium salt of N3.

The solution of the resultant salt in $30 \mathrm{~mL}$ acetone was dropwise added to a solution consisting of acetic anhydride $(1.5 \mathrm{~mL}, 0.014 \mathrm{M})$ and glacial acetic acid $(1 \mathrm{~mL}, 0.016 \mathrm{M})$. The reaction solution was heated with constant stirring for 1 hour in a water bath and then poured into a mixture of water and crushed ice. The solid was collected by filtration, washed with water and recrystallized from the EtOH to afford $\mathbf{S 4}$ (S for semisynthesized). The method used here is a modified method to that employed by (Sandhya et al., 2010).

(S4): Pale yellow powder; (1.92 g, 82\% yield); m.p 140 $143^{\circ} \mathrm{C} ; \lambda_{\text {max }}(\mathrm{EtOH}) 492 \mathrm{~nm} ; \mathrm{R}_{\mathrm{f}} 0.803$; IR $\left(\mathrm{v}, \mathrm{cm}^{-1}\right): 3078(=\mathrm{C}-\mathrm{H}$ str.), 2897 (C-H str., alkyl), 1706, 1690 (C=O str., ester), 1677 $(\mathrm{C}=\mathrm{C}$ str.), 1577 ( $\mathrm{C}=\mathrm{C}$ str., aromatic), 1298 (asymmetrical C-O-C str., ether), 1170 (C-O str., ester), 1063 (symmetrical C-O-C str., ether); ${ }^{1} \mathrm{H}-\mathrm{NMR}\left(\mathrm{CDCl}_{3}, 300 \mathrm{MHz}\right) \delta \mathrm{ppm}: 7.8(\mathrm{~d}, 1 \mathrm{H}, J=9 \mathrm{~Hz}$, C5-H), 6.9 (d, 1H, J=9 Hz, C6-H), 6.85 (s, 1H, C8-H), 5.6 (s, 1H, $\mathrm{C} 3-\mathbf{H}), 3.5$ (s, 3H, O-CH $), 2.0$ (s, 3H, C7-OCO-CH $) ;{ }^{13} \mathrm{C}-\mathrm{NMR}$ $\left(\mathrm{CDCl}_{3}, 100 \mathrm{MHz}\right) \delta \mathrm{ppm}: 176.5(\mathrm{C} 4), 169.0\left(\mathrm{C} 7-\mathrm{OCO}-\mathrm{CH}_{3}\right)$, 164.2 (C2), 155.3 (C7), 150.0 (C9), 126.1 (C5), 120.3 (C10), 118.5 (C6), 114.3 (C8), 90.1 (C3), $52.2\left(\mathrm{O}-\mathrm{CH}_{3}\right), 15.5\left(\mathrm{C} 7-\mathrm{OCO}-\mathrm{CH}_{3}\right)$.

\section{Synthesis of 8-Acetyl-7-hydroxy-4-methoxycoumarin (S5)}

A mixture of $\mathbf{S 4}(1.17 \mathrm{~g}, 5 \mathrm{mmol})$ and anhydrous $\mathrm{AlCl}_{3}$ $(2.2 \mathrm{~g}, 16.5 \mathrm{mmol})$ in $40 \mathrm{~mL}$ dry $\mathrm{ACN}$ was reflexed $\left(85^{\circ} \mathrm{C}\right)$ for 4 hours. The cloudy solution was slowly and carefully poured into 20 $\mathrm{mL}$ of $1 \mathrm{M} \mathrm{HCl}$ at $0^{\circ} \mathrm{C}$ to destroy the excess of $\mathrm{AlCl}_{3}$. The mixture was extracted with ethyl acetate $(2 \times 30 \mathrm{~mL})$ that was sequentially washed with $20 \mathrm{~mL}$ of $5 \% \mathrm{NaHCO}_{3}$ solution, $20 \mathrm{~mL}$ of saturated $\mathrm{NaCl}$ solution and $20 \mathrm{~mL}$ of distilled $\mathrm{H}_{2} \mathrm{O}$. The ethyl acetate layer was dried over anhydrous $\mathrm{Na}_{2} \mathrm{SO}_{4}$, filtered and evaporated under reduced pressure. $\mathbf{S 5}$ was recrystallized from a mixture of EtOH: $\mathrm{CHCl}_{3}$ (1:2). This synthetic method is a modified one to that reported by (Traven et al., 2000).

(S5): Yellowish powder; (0.73 g, 63\% yield); m.p 171$173^{\circ} \mathrm{C} ; \lambda_{\max }(\mathrm{EtOH}) 543 \mathrm{~nm} ; \mathrm{R}_{\mathrm{f}} 0.746$; IR $\left(\mathrm{v}, \mathrm{cm}^{-1}\right): 3316$ (O-H str., phenol), 3058 (=C-H str.), 2858 (C-H str., alkyl), 1712 (C=O str., ester), 1668 ( $\mathrm{C}=\mathrm{O}$ str., ketone), 1570 ( $\mathrm{C}=\mathrm{C}$ str., aromatic), 1303 (asymmetrical C-O-C str., ether), 1172 (C-O str., ester), 1063 (symmetrical C-O-C str., ether); ${ }^{1} \mathrm{H}-\mathrm{NMR}\left(\mathrm{CDCl}_{3}, 300 \mathrm{MHz}\right) \delta$ ppm: 11.5 (s, 1H, O-H), 7.9 (d, 1H, $J=9 \mathrm{~Hz}, \mathrm{C} 5-\mathbf{H}), 6.8$ (d, 1H, $J=9 \mathrm{~Hz}, \mathrm{C6}-\mathbf{H}), 5.2$ (s, 1H, C3-H), 3.5 (s, 3H, O-CH ), 2.8 (s, $\left.3 \mathrm{H}, \mathrm{C} 8-\mathrm{CO}-\mathrm{CH}_{3}\right) ;{ }^{13} \mathrm{C}-\mathrm{NMR}\left(\mathrm{CDCl}_{3}, 100 \mathrm{MHz}\right) \delta \mathrm{ppm}: 196.1$ (C8-CO-CH $), 176.1$ (C4), 162.6 (C2), 157.9 (C7), 157.4 (C9), 130.2 (C5), 122.5 (C8), 121.4 (C10), 110.1 (C6), 90.1 (C3), 51.2 $\left(\mathrm{O}-\mathrm{CH}_{3}\right), 24.2\left(\mathrm{C} 8-\mathrm{CO}-\mathrm{CH}_{3}\right)$.

\section{Synthesis of 4,7-Dimethoxycoumarin (S6)}

To a stirred mixture of $\mathbf{N 3}(1.92 \mathrm{~g}, 10 \mathrm{mmol})$ and anhydrous $\mathrm{K}_{2} \mathrm{CO}_{3}(2.76 \mathrm{~g}, 20 \mathrm{mmol})$ in $90 \mathrm{~mL}$ dry acetone, a solution of dimethyl sulfate (DMS) $(1.15 \mathrm{~mL}, 12 \mathrm{mmol})$ in 10 $\mathrm{mL}$ dry acetone was dropwise added. The reaction mixture was refluxed for 3 hours under anhydrous conditions and filtered; the inorganic salts were washed several times with hot acetone (10 $\mathrm{mL}$ ). The combined acetone solution was concentrated under reduced pressure; heated to $50^{\circ} \mathrm{C}$ and directly poured into a mixture of water and crushed ice. The precipitate was filtered, washed with water and recrystallized from a mixture of methanol: ether (3:1) to afford S6. This is a modified method to that reported by (Karteek et al., 2015).

(S6): White powder; (1.44 g, $70 \%$ yield); m.p 149$152^{\circ} \mathrm{C} ; \lambda_{\text {max }}(\mathrm{EtOH}) 320 \mathrm{~nm} ; \mathrm{R}_{\mathrm{f}} 0.824 ; \mathrm{IR}\left(\mathrm{v}, \mathrm{cm}^{-1}\right): 3063(=\mathrm{C}-\mathrm{H}$ str.), 2892, 2838 (C-H str., alkyl), 1700 (C=O str., ester), 1596 $(\mathrm{C}=\mathrm{C}$ str., aromatic), 1310 (asymmetrical C-O-C str., ether), 1148 (C-O str., ester), 1042 (symmetrical C-O-C str., ether); ${ }^{1} \mathrm{H}-\mathrm{NMR}$ $\left(\mathrm{CDCl}_{3}, 300 \mathrm{MHz}\right) \delta$ ppm: $7.4(\mathrm{~d}, 1 \mathrm{H}, J=9 \mathrm{~Hz}, \mathrm{C} 5-\mathrm{H}), 6.6(\mathrm{~d}$, $1 \mathrm{H}, J=9 \mathrm{~Hz}, \mathrm{C} 6-\mathrm{H}), 6.5$ (s, 1H, C8-H), 5.4 (s, 1H, C3-H) 3.7 (s, $\left.3 \mathrm{H}, \mathrm{C} 7-\mathrm{O}-\mathrm{CH}_{3}\right), 3.3$ (s, 3H, C4-O-CH $) ;{ }^{13} \mathrm{C}-\mathrm{NMR}\left(\mathrm{CDCl}_{3}, 100\right.$ $\mathrm{MHz}) \delta$ ppm: 173.5 (C4), 162.6 (C2), 160.1 (C7), 150.1 (C9), 130.0 (C5), 119.0 (C10), 111.9 (C6), 107.5 (C8), 94.3 (C3), 58.0 $\left(\mathrm{C} 7-\mathrm{O}-\mathrm{CH}_{3}\right), 50.6\left(\mathrm{C} 4-\mathrm{O}-\mathrm{CH}_{3}\right)$.

\section{CYTOTOXICITY STUDY}

The cancer cell lines on which the cytotoxic effects of the studied compounds were tested were MCF-7, AMN3, and HeLa. They were obtained from Iraq Biotech Cell Bank Unit and maintained in a medium composed of RPMI 1640 supplemented with fetal bovine serum (heat-inactivated, 10\%), 100 units $/ \mathrm{mL}$ penicillin, and $100 \mu \mathrm{g} / \mathrm{mL}$ streptomycin. The harvest cells were passaged via Trypsin-EDTA, reseeded at 50\% confluence twice weekly, and incubated in $5 \% \mathrm{CO}_{2}$ environment at $37^{\circ} \mathrm{C}$ (Attar et al., 2017).

MTT cell viability test was performed to determine the cytotoxic effect of the isolated and semisynthetic coumarins using 96-well plates. The cell line was seeded at $1 \times 10^{4}$ cells/well and after 24 hours it was treated separately with each of the tested compounds. Later than 72 hours of treatment, cell viability was measured by removing the medium, adding $28 \mu \mathrm{l}$ of $2 \mathrm{mg} / \mathrm{mL}$ solution of MTT and incubating the cells for 1.5 hours at $37^{\circ} \mathrm{C}$. As MTT solution was removed, the crystals remaining in the wells were solubilized by the addition of $130 \mu \mathrm{l}$ DMSO followed by 
incubation at $37^{\circ} \mathrm{C}$ for 15 minutes with shaking (Al-Shammari et al., 2016).

The absorbance was determined on a microplate reader at $492 \mathrm{~nm}$ and the assay was performed in triplicate. The inhibition rate of cell growth (the percentage of cytotoxicity) was calculated according to the following equation: Inhibition rate $=(\mathrm{A}-\mathrm{B}) / \mathrm{A} \times$ 100 , where $\mathrm{A}$ is the mean optical density of untreated wells, and $\mathrm{B}$ is the optical density of treated wells (Shahneh et al., 2013).

\section{RESULTS AND DISCUSSION}

In the recent years, natural products and their semisynthetic derivatives are gaining more and more popularity as potential drugs for the treatment of various illnesses affecting human beings (Atanasov et al., 2015; Sanjeewa et al., 2016).

Because apple is the fourth most consumed fruit in the world, and because of several lines of evidence which indicate that apple and its constituents have a wide range of pharmacological properties (White et al., 2013) and ratified to the ancient saying "an apple a day keeps the doctor away", our team targeted the isolation and identification of coumarins present in Creston apple seeds.

Table 1: Phytochemical analysis of extracts obtained from serial Soxhlet extraction in the order of decreasing polarity. The solvent columns are arranged according to polarity starting from the most polar to the left.

\begin{tabular}{ccccc}
\hline Phytoconstituents & $\begin{array}{c}\text { Water } \\
\text { extract }\end{array}$ & $\begin{array}{c}\text { Methanol } \\
\text { extract }\end{array}$ & $\begin{array}{c}\text { Chloroform } \\
\text { extract }\end{array}$ & $\begin{array}{c}\text { n-hexane } \\
\text { extract }\end{array}$ \\
\hline Flavonoids & + & + & - & - \\
Coumarins & - & + & + & - \\
Tannins & - & - & - & - \\
Terpenoid & - & + & + & - \\
Carbohydrates & + & + & - & - \\
Alkaloids & + & + & - & + \\
Fatty acids & - & - & + & - \\
Emodins & - & - & - & - \\
Anthraquinones & - & - & - & - \\
Betacyanine & + & + & - & - \\
Anthocyanine & - & - & - & - \\
Phenol & + & + & - & - \\
Protein & + & + & - & - \\
Amino acid & + & + & - & - \\
Steroids & - & + & - & - \\
Saponine & + & + & - & - \\
Glycosides & - & + & - & - \\
\hline
\end{tabular}

\section{PHYTOCHEMICAL ANALYSIS}

Qualitative phytochemical screening tests were carried out on three types of extracts; the first one was obtained from serial Soxhlet extraction in the order of decreasing polarity, the second was acquired using the same extraction method but in the order of increasing polarity, and the last type was attained from kinetic maceration method of extraction. Based on the results of the phytochemical analysis as showed in (Tables 1, 2 and 3), coumarins could be detected in methanol and chloroform extracts.
Table 2: Phytochemical analysis of extracts obtained from serial Soxhlet extraction in the order of increasing polarity. The solvent columns are arranged according to polarity starting from the most polar to the left.

\begin{tabular}{ccccc}
\hline Phytoconstituents & $\begin{array}{c}\text { Water } \\
\text { extract }\end{array}$ & $\begin{array}{c}\text { Methanol } \\
\text { extract }\end{array}$ & $\begin{array}{c}\text { Chloroform } \\
\text { extract }\end{array}$ & n-hexane extract \\
\hline Flavonoids & - & + & - & - \\
Coumarins & - & - & + & - \\
Tannins & - & - & - & - \\
Terpenoid & - & + & + & - \\
Carbohydrates & + & + & - & - \\
Alkaloids & + & + & - & - \\
Fatty acids & - & - & - & + \\
Emodins & - & - & - & - \\
Anthraquinones & - & - & - & - \\
Betacyanine & - & + & - & - \\
Anthocyanine & - & - & - & - \\
Phenol & - & + & + & - \\
Protein & - & + & + & - \\
Amino acid & - & + & + & - \\
Steroids & - & + & + & - \\
Saponine & + & + & - & - \\
Glycosides & - & - & - & \\
\hline & & & &
\end{tabular}

Table 3: Phytochemical analysis of extracts obtained from kinetic maceration method of extraction. The solvent columns are arranged according to polarity starting from the most polar to the left.

\begin{tabular}{ccccc}
\hline Phytoconstituents & Water extract & $\begin{array}{c}\text { Methanol } \\
\text { extract }\end{array}$ & $\begin{array}{c}\text { Chloroform } \\
\text { extract }\end{array}$ & $\begin{array}{c}\text { n-hexane } \\
\text { extract }\end{array}$ \\
\hline Flavonoids & + & + & - & - \\
Coumarins & - & + & + & - \\
Tannins & - & - & - & - \\
Terpenoid & - & + & + & - \\
Carbohydrates & + & + & - & - \\
Alkaloids & + & + & - & - \\
Fatty acids & - & - & + & + \\
Emodins & - & - & - & - \\
Anthraquinones & - & - & - & - \\
Betacyanine & + & + & - & - \\
Anthocyanine & - & - & - & - \\
Phenol & + & + & + & - \\
Protein & + & + & + & - \\
Amino acid & + & + & + & - \\
Steroids & - & + & + & - \\
Saponine & + & + & - & - \\
Glycosides & - & - & - & - \\
\hline
\end{tabular}

Coumarins can be present in both polar and nonpolar solvents. This can be due to more than one reason. For example, the types of substituents present on the isolated coumarin can make it soluble in more than one type of solvents. The amount of solvent used, which can be considered huge relative to the amount of the isolated coumarin could be another reason, where the coumarin will dissolve because of a large amount of solvent present (Hrdlovic et al., 2010). 


\section{ISOLATION OF COUMARINS}

One of the most important chemical characteristics of coumarins is the presence of cyclic ester that opens when attacked by a strong base like $\mathrm{NaOH}$ to give yellow solutions of the salts of the corresponding cis-cinnamic acids. These salts are recycled to original coumarins when acidified with a sufficient amount of strong acid. This chemical property as displayed in Scheme 2 was employed in this work to isolate coumarins from other phytoconstituents (Lopez-Castillo et al., 2013). According to the selected method of isolation and the presence or absence of flavonoids, the chloroform extract from serial Soxhlet extraction in the order of increasing polarity was chosen to identify its coumarin components.

\section{IDENTIFICATION OF ISOLATED COUMARINS}

Chemical structures of $\mathbf{N 1}, \mathbf{N} 2$ and $\mathbf{N} 3$ were identified by analyzing their FTIR, ${ }^{1} \mathrm{H}$ NMR and ${ }^{13} \mathrm{C}$ NMR spectra. For $\mathbf{N 1}$, the identification data showed the presence of characteristic chemical shifts of coumarin nucleus (Shults et al., 2003) and of the dihydropyran-2-one ring (Bonvin et al., 2005). For N2, the identification data reported the presence of characteristic chemical shifts of coumarin nucleus substituted at positions 6 and 7 (Perel'son et al., 1970) and of coumarin nucleus substituted at position 5 with ethyl group (Appendino et al., 1999). For N3, the identification data informed the presence of characteristic chemical shifts of 7-hydroxycoumarin substituted at position 4 (Ramesh et al., 2008). Accordingly, the chemical structures of N1, N2, and N3 were elucidated as displayed in Fig. 1.<smiles>O=C1OCCc2cc3oc(=O)ccc3cc21</smiles>

5,6-dihydropyrone(4,3-g)coumarin (N1)<smiles>COc1cc(=O)oc2cc(O)ccc12</smiles>

Fig. 1: Chemical structures of coumarin and of coumarins isolated from Creston apple seeds.<smiles>COc1cc(=O)oc2cc(OC(C)=O)ccc12</smiles>

(S4)<smiles>COc1cc(=O)oc2c(C(C)=O)c(O)ccc12</smiles>

$\Delta \mathbf{H}^{\circ}{ }_{\mathrm{r}}=-120.44$<smiles>COc1cc(=O)oc2cc(O)c(C(C)=O)cc12</smiles>

6-acetyl- isomer

Fig. 2: Heat of formation of each of $\mathbf{S 5}$ and its 6-acetyl-isomer expressed in kcal/mol.

\section{CHEMICAL SYNTHESIS OF COMPOUND (N3) DERIVATIVES}

\section{7-Acetoxy-4-methoxycoumarin (S4)}

It was synthesized by condensing N3 with acetic anhydride; both reactants have been activated prior to their condensation by enhancing the nucleophilicity of phenolic hydroxyl group as it is converted to metal phenoxide and by improving the electrophilicity of carbonyl carbon of acetic anhydride when it is protonated via glacial acetic acid (Habibi et al., 2013).
Identification data of $\mathbf{S} 4$ reported the absence of the chemical shift of phenolic hydroxyl group resonated at $10.1 \mathrm{ppm}$ found in the ${ }^{1} \mathrm{H}-\mathrm{NMR}$ spectrum of $\mathbf{N} 3$ and the appearance of the chemical shift of acetate methyl group resonated at $2.0 \mathrm{ppm}$. This confirmed the formation of acetate ester linkage at position 7 of S4.

\section{8-Acetyl-7-hydroxy-4-methoxycoumarin (S5)}

It was synthesized by heating $\mathbf{S} 4$ with an excess of $\mathrm{AlCl}_{3}$ at $85^{\circ} \mathrm{C}$ in a Fries rearrangement reaction. At that temperature, 
S4 is the predominant product comparing with its 6-acetylisomer (Traven, 2004), this is mainly due to kinetic factors since both, $\mathbf{S 5}$ and its 6-acetyl- isomer, have approximately the same thermodynamic stability (Fig. 2) according to AM1 calculation that was performed using Scigress Explorer software (Fujitsu, Japan).<smiles>COc1cc(=O)oc2cc(O)ccc12</smiles>

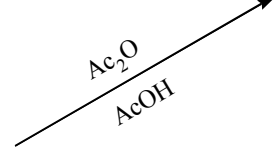<smiles>COc1cc(=O)oc2cc(OC(C)=O)ccc12</smiles>

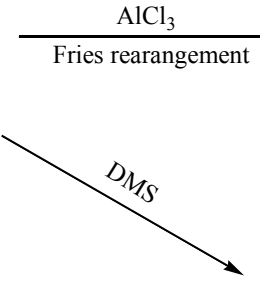<smiles>COc1cc(=O)oc2c(C(C)=O)c(O)ccc12</smiles>

N3

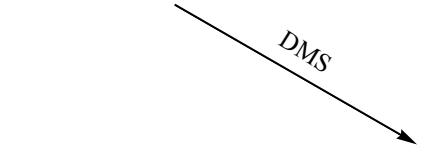<smiles>COc1ccc2c(OC)cc(=O)oc2c1</smiles>

Scheme 1: Synthetic pathways of N3 derivatives.

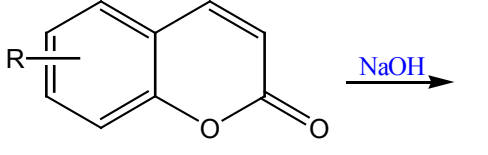

Coumarin derivative

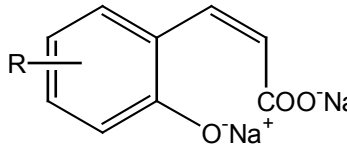

Disodium salt of cis-cinnamic acid derivative
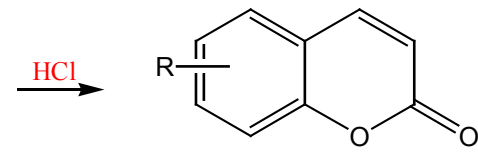

Coumarin derivative

Scheme 2: base-catalyzed ring opening of coumarin derivatives and their recycling by strong acid.

Identification data of $\mathbf{S 5}$ reported the presence of the chemical shifts of phenolic hydroxyl group resonated at 11.5 and the chemical shift of acyl methyl group resonated at $2.8 \mathrm{ppm}$. This confirmed the rearrangement of phenolic ester found in $\mathbf{S} 4$ into O-hydroxy aryl ketone present in the chemical structure of S5.

\section{4,7-Dimethoxycoumarin (S6)}

DMS is one of the most commonly used reagents for methylation of O-, $\mathrm{N}$ - and $\mathrm{S}$-functional groups, and it is miscible with many solvents such as ether, acetone, and dioxane that must be dry since it is hydrolyzed by water (Selva and Perosa, 2008).

The synthesis of $\mathbf{S 6}$ is similar in scope to Haworth methylation (DMS with 30\% aqueous $\mathrm{NaOH}$ ) (Lamoureux and Agüero, 2009) but it is different in the type of base. $\mathrm{K}_{2} \mathrm{CO}_{3}$ was used instead of $\mathrm{NaOH}$, which can open the coumarin lactone ring of S6, to initiate the deprotonation of phenolic hydroxyl group enhancing its nucleophilicity and to neutralize the acidity of methyl hydrogen sulfate byproduct (Bernini et al., 2011).

Identification data of S6 reported the absence of the chemical shift of phenolic hydroxyl group resonated at $10.1 \mathrm{ppm}$ found in the ${ }^{1} \mathrm{H}-\mathrm{NMR}$ spectrum of $\mathbf{N} \mathbf{3}$ and the appearance of the chemical shift of methoxy group resonated at $3.7 \mathrm{ppm}$. This confirmed the formation of methyl ether bond at position 7 of $\mathbf{S 6}$.

\section{CYTOTOXICITY STUDY}

Tables 4 indicated that $\mathbf{N 1}$ and $\mathbf{N 2}$ have $\mathrm{IC}_{50}$ values higher than that of positive control against MCF-7 cancer cell line as calculated by using the MTT assay. The results also showed that N3, S4, S5, and S6 have $\mathrm{IC}_{50}$ values lower than that of the positive control, with the best cytotoxic activity attributed to S6. Accordingly, these compounds may be considered as potential cytotoxic agents for the treatment of breast cancer.

The results also showed that the isolated and semisynthetic compounds have $\mathrm{IC}_{50}$ values higher than that of positive control against AMN3 cancer cell line with the best cytotoxic activity attributed to S6. Accordingly, this compound may be considered as a candidate cytotoxic agent for the treatment of mammary gland cancer.

In addition, the results presented in (Table 4) revealed that the isolated and semisynthetic compounds have $\mathrm{IC}_{50}$ values higher than that of positive control against HeLa cancer cell line 
with the best cytotoxic activity attributed to S5. Accordingly, this compound may be considered as a candidate cytotoxic agent for the treatment of cervical cancer.

Table 4: Mean $\pm \mathrm{SD} \mathrm{IC}_{50}$ values of positive control, natural and semisynthetic coumarin derivatives against MCF-7, AMN3 and HeLa cancer cell lines.

\begin{tabular}{cccc}
\hline \multirow{2}{*}{ Compound Name } & MCF-7 & AMN3 & HeLa \\
\cline { 2 - 4 } & $\begin{array}{c}\mathbf{I C}_{50} \\
(\boldsymbol{\mu g} / \mathbf{m L})\end{array}$ & $\begin{array}{c}\mathbf{I C}_{50} \\
(\boldsymbol{\mu g} / \mathbf{m L})\end{array}$ & $\begin{array}{c}\mathbf{I C}_{50} \\
(\boldsymbol{\mu g} / \mathbf{m L})\end{array}$ \\
\hline 5- Fluorouracil & $12.50 \pm 1.477$ & $15.20 \pm 2.621$ & $11.90 \pm 0.737$ \\
N1 & $36.80 \pm 2.788$ & $75.20 \pm 5.834$ & $37.50 \pm 3.722$ \\
N2 & $26.20 \pm 1.324$ & $49.20 \pm 4.475$ & $39.22 \pm 2.576$ \\
N3 & $9.83 \pm 1.135$ & $35.60 \pm 2.763$ & $37.83 \pm 3.682$ \\
S4 & $8.30 \pm 0.449$ & $41.30 \pm 3.286$ & $42.30 \pm 6.772$ \\
S5 & $12.48 \pm 0.572$ & $32.50 \pm 1.406$ & $21.50 \pm 1.52$ \\
S6 & $8.22 \pm 0.321$ & $21.22 \pm 1.804$ & $23.52 \pm 1.372$ \\
\hline
\end{tabular}

Mean $\pm \mathrm{SD} \mathrm{IC}_{50}$ values were determined by MTT assays following $72 \mathrm{~h}$ exposure of cells to test compounds $(\mathrm{n}=3)$ and expressed as a mean and standard deviation of 3 independent trials.

\section{CONCLUSION}

Two extraction methods (Soxhlet extraction and kinetic maceration) performed on Creston apple seeds revealed the presence of coumarin derivatives in the chloroform extract. These natural coumarin derivatives were isolated, purified and characterized; one of them was chemically modified affording three semisynthetic coumarin derivatives. The in vitro cytotoxic activity of the isolated and semisynthetic coumarins using MTT assay on three different cancer cell lines indicated that N3, S4, S5, and $\mathbf{S 6}$ have a significant cytotoxic activity against MCF-7 cancer cell line. Also, S6 showed an encouraging cytotoxic activity against AMN3 while $\mathbf{S 5}$ showed the same activity against HeLa cancer cell line.

\section{CONFLICT OF INTERESTS}

There are no conflicts of interest.

\section{REFERENCES}

Al-Shammari AM, Salman MI, Saihood YD, Yaseen NY, Raed K, Shaker HK, Ahmed A, Khalid A, Duiach A. In vitro synergistic enhancement of newcastle disease virus to 5-Fluorouracil cytotoxicity against tumor cells. Biomedicines, 2016; 4. https://doi.org/10.3390/ biomedicines 4010003 .

Anbu Jeba Sunilson J, Anita Gnana Kumari AV, Khan A, Anandarajagopal K. Effects of Malus domestica fruit extracts against clinically isolated dental pathogens. Eur J Dent Med, 2016; 8:12-16. http:// dx.doi.org/10.3923/ejdm.2016.12.16.

Appendino G, Cravotto G, Giovenzana GB, Palmisano G. A Straightforward Entry into Polyketide Monoprenylated Furanocoumarins and Pyranocoumarins. J Nat Prod, 1999; 62:1627-1631.

Apu AS, Liza MS, Jamaluddin AT, Howlader MA, Saha RK, Rizwan F, Nasrin N. Phytochemical screening and in vitro bioactivities of the extracts of aerial part of Boerhavia diffusa Linn. Asian Pac J Trop Biomed, 2012; 2:673-678.

Atanasov AG, Waltenberger B, Pferschy-Wenzig E, Linder T, Wawrosch C, Uhrin P, Temml V, Wang L, Schwaiger S, Heiss EH, Rollinger JM, Schuster D, Breuss JM, Bochkov V, Mihovilovic MD, Kopp B, Bauer R, Dirsch VM, Stuppner H. Discovery and resupply of pharmacologically active plant-derived natural products: A review. Biotechnol Adv, 2015; 33:1582-1614.
Attar R, Cincin ZB, Bireller ES, Cakmakoglu B. Apoptotic and genomic effects of corilagin on SKOV3 ovarian cancer cell line. Onco Targets Ther, 2017; 10:1941-1946.

Bernini R, Crisante F, Ginnasi MC. A convenient and safe O-methylation of flavonoids with dimethyl carbonate (DMC). Molecules, 2011; 16:1418-1425. https://doi.org/10.3390/molecules16021418.

Bonvin Y, Callens E, Larrosa I, Henderson DA, Oldham J, Burton AJ, et al. Bismuth-catalyzed benzylic oxidations with tert-butyl hydroperoxide. Org. Lett., 2005; 7:4549-4552.

Crane EA, Gademann K. Capturing biological activity in natural product fragments by chemical synthesis. Angew Chem Int Ed Engl, 2016; 55:3882-3902.

Ghanbari K, Aghajani H, Golbabaee M, Khah EN, Nabavi SH, Koohian A. Column chromatography: A facile and inexpensive procedure to purify the red dopant DCJ applied for OLEDs. Adv Mat Phy Chem, 2011; 1:91-93. http://dx.doi.org/10.4236/ampc.2011.13015.

Habibi D, Rahmani P, Akbaripanah Z. Acetylation of phenols, anilines, and thiols using silica sulfuric acid under solvent-free conditions. J Chem, 2013; 2013. http://dx.doi.org/10.1155/2013/268654.

Harborne JB, 1998. Phytochemical methods: A guide to modern techniques of plant analysis. Second ed. London: Chapmann and Hall Publishers.

Hrdlovic P, Donovalova J, Stankovicova H, Gaplovsky A. Influence of polarity of solvents on the spectral properties of bichromophoric coumarins. Molecules, 2010; 15:8915-8932. http://dx.doi:10.3390/ molecules15128915.

Jelodarian S, Haghir Ebrahimabadi A, Khalighi A, Batooli H. Evaluation of antioxidant activity of Malus domestica fruit extract from Kashan area. Avicenna J Phytomed, 2012; 2:139-145.

Karteek SD, Rao MVB, Yeggoni DP, Adeppa K, Darla SS Manidhar DM. Design, synthesis and molecular docking of 2-iso propyl amino derivatives of 7-methoxy coumarin as potent acetylcholinesterase inhibitors. Der Pharma Chemica, 2015; 7:255-272. https://www. researchgate.net/publication/281717418.

Kok TM, Breda SG, Briede JJ. Genomics-based identification of molecular mechanisms behind the cancer preventive action of phytochemicals: potential and challenges. Curr Pharm Biotechnol, 2012; 13:255-264.

Konarska A. The structure of the fruit peel in two varieties of Malus domestica Borkh. (Rosaceae) before and after storage. Protoplasma, 2013; 250:701-714

Lamoureux G, Agüero C. A comparison of several modern alkylating agents. ARKIVOC, 2009; 2009:251-264. http://dx.doi. org/10.3998/ark.5550190.0010.108.

Liaudanskas M, Viskelis P, Raudonis R, Kviklys D, Uselis N, Janulis V. Phenolic composition and antioxidant activity of Malus domestica leaves. Sci World J, 2014; 2014. http://dx.doi.org/10.1155/2014/306217.

Li-Weber M. Molecular mechanisms and anti-cancer aspects of the medicinal phytochemicals rocaglamides (=flavaglines). Int J Cancer, 2015; 137:1791-1799.

Lopez-Castillo NN, Rojas-Rodriguez AD, Porta1 BM, CruzGomez MJ. Process for the obtention of coumaric acid from coumarin: Analysis of the reaction conditions. Adv Chem Eng Sci, 2013; 3:195-201. http://dx.doi.org/10.4236/aces.2013.33025.

Mahlo SM, Chauke HR, McGaw L, Eloff J. Antioxidant and antifungal activity of selected medicinal plant extracts against phytopathogenic fungi. Afr J Tradit Complement Altern Med, 2016; 13:216-222.

Naviglio D, Formato A, Vitulano M, Cozzolino I, Ferrara L, Zanoelo EF, Gallo M. Comparison between the kinetics of conventional maceration and a cyclic pressurization extraction process for the production of lemon liqueur using a numerical model. J Food Process Eng, 2016; 40. http://dx.doi.org/10.1111/jfpe.12350.

Nelson LS, Shih RD, Balick MJ. 2007. Handbook of poisonous and injurious plants. $2^{\text {nd }}$ ed. Springer, New York, pp. 211-212. ISBN 978-0387-33817-0. Retrieved 9 February 2018. 
Newman DJ, Cragg GM. Natural products as sources of new drugs from 1981 to 2014. J Nat Prod, 2016; 79:629-661.

Perel'son ME, Sheinker YN, Syrova GP, Turchin KF. NMR spectra of natural coumarins. Translated from Khimiya Prirodnykh Soedinenii, 1970; 6:6-14.

Quamme HA, Lapins KO, Schmidt H, MacDonald RA, Lane WD, Hampson CR. Creston apple. Can J Plant Sci, 1999; 79:291-294. https://doi.org/10.4141/P98-083.

Ramesh P, Das AT, Mohandass P, Nagasathya R. The structure of Hantzsch coumarin. Indian J Chem, 2008; 47B:1447-1450.

Rosselli S, Maggio AM, Faraone N, Spadaro V, Morris-Natschke SL, Bastow KF, Lee KH, Bruno M. The cytotoxic properties of natural coumarins isolated from roots of Ferulago campestris (Apiaceae) and of synthetic ester derivatives of aegelinol. Nat Prod Commun, 2009; 4:17011706.

Sandhya B, Mathew V, Lohitha P, Ashwini T, Shravani A. Synthesis, characterization and pharmacological activities of coumarin derivatives. Int J Chem Pharm Sci, 2010; 1:16-25.

Sanjeewa KKA, Kim EA, Son KT, Jeon YJ. Bioactive properties and potentials cosmeceutical applications of phlorotannins isolated from brown seaweeds: A review. J Photochem Photobiol B, 2016; 162:100-105.

Selva M, Perosa A. Green chemistry metrics: a comparative evaluation of dimethyl carbonate, methyl iodide, dimethyl sulfate and methanol as methylating agents. Green Chem, 2008; 10:457-464. https:// doi.org/10.1039/B713985C.

Shahneh FZ, Valiyari S, Azadmehr A, Hajiaghaee R, Yaripour S, Bandehagh A, Baradaran B. Inhibition of growth and induction of apoptosis in fibrosarcoma cell lines by Echinophora platyloba DC: In vitro analysis. Adv Phar Sci, 2013. http://dx.doi.org/10.1155/2013/512931.

Shullts ES, Petrova TN, Shakirov MM, Chernyak EI, Pokrovskiy LM, Nekhoroshev SA, Tolstikov GA.Coumarin compounds from Root of Peucedanum (Peucedanum morisonii Bess.). Chem Sust Dev, 2003; 11:649-654

Siegel RL, Miller KD, Jemal A. Cancer Statistics, 2018. CA. Cancer J Clin, 2018; 68:7-30.

Sowa A, Zgorka G, Szykula A, Franiczek R, Zbikowska B, Gamian A, Sroka Z. Analysis of polyphenolic compounds in extracts from leaves of some Malus domestica cultivars: Antiradical and antimicrobial analysis of these extracts. Biomed Res Int, 2016; 2016. http://dx.doi. org/10.1155/2016/6705431.

Stefanachi A, Leonetti F, Pisani L, Catto M, Carotti A. Coumarin: A natural, privileged and versatile scaffold for bioactive compounds. Molecules, 2018; 23. https://doi.org/10.3390/molecules23020250.

Swayam SS, Smita S, Subhangankar N, Himanshu BS. Synthesis of novel coumarin derivatives and its biological evaluations. Euro J Exp Bio, 2012; 2:899-908.

Traven VF, Podhaluzina NY, Vasilyev AV, Manaev AV. Unusual Fries rearrangement of 7-acyloxyquinolin-2-ones-A new way to linear and angular furoquinolin-2-ones. ARKIVOC, 2000; 6:931-938. http://dx.doi. org/10.3998/ark.5550190.0001.611.

Traven VF. New synthetic routes to furocoumarins and their analogs: A review. Molecules, 2004; 9:50-66. http://dx.doi. org/10.3390/90300050.

Tsuchiya H. Membrane interactions of phytochemicals as their molecular mechanism applicable to the discovery of drug leads from plants. Molecules, 2015; 20:18923-18966.

Venugopala KN, Rashmi V, Odhav B. Review on natural coumarin lead compounds for their pharmacological activity. Biomed Res Int, 2013; 2013. http://dx.doi.org/10.1155/2013/963248.

Vineetha VP, Girija S, Soumya RS, Raghu KG. Polyphenol-rich apple (Malus domestica L.) peel extract attenuates arsenic trioxide induced cardiotoxicity in H9c2 cells via its antioxidant activity. Food Funct, 2014; 5:502-511.

White BA, Horwath CC, Conner TS. Many apples a day keep the blues away--daily experiences of negative and positive affect and food consumption in young adults. Br J Health Psychol, 2013; 18:782-798. https://doi.org/10.1111/bjhp.12021.

How to cite this article:

Mustafa YF, Najem MA, Tawffiq ZS. Coumarins from Creston Apple Seeds: Isolation, Chemical Modification, and Cytotoxicity Study. J App Pharm Sci, 2018; 8(08): 049-056. 